\title{
RESPON MAHASISWA TERHADAP BUKU AJAR MORFOLOGI BAHASA ARAB BERBASIS ANALISIS KONTRASTIF
}

\author{
Siti Sulaikho, S.Pd.I, M.Pd \\ Dosen Prodi Pendidikan Bahasa Arab Fakultas Agama Islam \\ Universitas KH. A. Wahab Hasbullah Jombang \\ ikho.zul@unwaha.ac.id \\ Lailatul Mathoriyah, S.Pd, M.Pd. \\ Dosen Prodi Pendidikan Bahasa Arab Fakultas Agama Islam \\ Universitas KH. A. Wahab Hasbullah Jombang \\ lelymathoriyah1982@gmail.com
}

\begin{abstract}
Learning Arabic morphology that is not a mother tongue is not an easy matter. Based on the questionnaire given to students, the problem they faced in studying Arabic morphology was that it was difficult to distinguish the terms contained in Arabic morphology by $22.9 \%$, the examples used were always the same in each discussion so as to confuse $14.3 \%$, difficult to find examples other than those already explained by $17.1 \%$, one word can be changed into many other forms by $8.6 \%$, not knowing the meaning of each word change by $14.3 \%$, difficult to translate into Indonesian so it is not easily understood $11.4 \%$, and it is difficult to get an easily understood learning source of $11.4 \%$. This study aims to determine the response of Arabic Language Education study program students at the University of KH. A. Wahab Hasbullah towards Arabic Morphology textbook based on contrastive analysis using quantitative approaches. Student response data collection using a questionnaire instrument. 35 students were conditioned in one room and gave an assessment of the textbooks that had been shown to them. The final results of the 15 assessment points showed that the Arabic Morphology Textbook Based on Contrastive Analysis scored 90.8 with a decent category and a very good predicate.
\end{abstract}

Keyword : Morphology, Arabic, Contrastive Analysis, Textbooks.

\section{Pendahuluan}

Bahasa kedua atau bahasa target dapat dikuasai melalui dua cara, yaitu pemerolehan dan pembelajaran bahasa. Dalam pemerolehan, bahasa dikuasai dengan tidak disadari dan bersifat alamiah, sedangkan pembelajaran bahasa merupakan usaha yang disadari untuk mengetahui tentang suatu bahasa.

Perbedaan lain dari keduanya adalah pemerolehan bahasa merupakan hasil dari 


\section{Siti Sulaikho', Lailatul Mathoriyah.}

komunikasi praktis yang dilakukan secara aktif, sedangkan pembelajaran bahasa bertujuan untuk menguasai kaidah-kaidah kebahasaan secara mendalam. ${ }^{1}$ Kaidah bahasa yg dimaksud diantaranya adalah kajian morfologi.

Morfologi mengkaji tentang struktur kata sebelum menjadi kalimat. ${ }^{2}$ Morfologi bahasa Arab atau șaraf adalah kajian tentang perubahan struktur kata, baik berupa penambahan huruf, pengurangan, maupun penggantian huruf. ${ }^{3}$

Satu kata dalam bahasa Arab, dapat berubah menjadi 8 hingga 12 bentuk yang berbeda. Perubahan-perubahan bentuk ini memberikan arti yang berbeda pula. Dengan banyaknya ketentuan baku dan bentuk perubahan di dalamnya, seringkali ditemukan kesalahan dalam pemilihan kata yang digunakan sehingga menyebabkan maksud yang diinginkan tidak tersampaikan dengan baik.

Salah satu kendala yang menjadikan morfologi bahasa Arab sulit dipelajari adalah sedikitnya bahan pustaka yang menyajikan materi morfologi bahasa Arab yang dikontraskan dengan morfologi bahasa Indonesia. Sementara cara mudah untuk menguasai morfologi bahasa Arab sebagai bahasa target adalah memperbandingkan dengan bahasa Indonesia yang merupakan bahasa ibu. ${ }^{4}$

Dalam proses memperbandingkan ini akan ditemukan persamaan dan perbedaan diantara keduanya. Persamaan kaidah menyebabkan penguasaan morfologi bahasa Arab menjadi lebih mudah dikuasai. Sebaliknya, perbedaan kaidah dapat menyebabkan penguasaan

\footnotetext{
${ }^{1}$ Pringgawidagda, Suwarna. 2002. Strategi Penguasaan Berbahasa. Yogyakarta: Adicita Karya Nusa, hlm. 17-19.

2 John Lyons, Pengantar Teori Linguistik (Jakarta: Gramedia Pustaka Utama, 1995), 190.

${ }^{3}$ Muhamad Ichsan Maulana, Belajar Shorof Tanpa Guru (Kediri: Lirboyo Press, 2015$), 15$.

${ }^{4}$ Yayan Nurbayan, "Pengembangan Materi Ajar Balaghah Berbasis Pendekatan Kontrastif". Jurnal Bahasa dan Seni, Volume 38 No. 1, Februari( 2010) : 107-116, diakses pada 4 Agustus 2019.
} 


\section{Respon Mahasiswa Terhadap Buku Ajar Morfologi Bahasa Arab Berbasis Analisis}

Kontrastif

morfologi bahasa Arab lebih sulit dipelajari. ${ }^{5}$

Berdasarkan permasalahan ini, maka disusun lah buku ajar Morfologi Bahasa Arab Berbasis Analisis Konstrastif yang bertujuan untuk mempermudah dalam mempelajari morfologi bahasa Arab. Buku ajar ini ditujukan untuk mahasiswa Prodi Bahasa Arab di Universitas KH. A. Wahab Hasbullah. Buku ajar Morfologi Bahasa Arab Berbasis Analisis Konstrastif menjadi istimewa karena menggunakan analisis kontrastif sebagai acuan dalam menyajikan materi.

Penyusunan buku ajar Morfologi Bahasa Arab Berbasis Analisis Konstrastif menggunakan prinsip penelitian dan pengembangan atau Research and Development (R\&D) dengan pendekatan kualitatif dan pendekatan kuantitatif. Model pengembangan mengadopsi dari Borg and Gall yang mencakup 10 langkah umum, yaitu research and information collecting, planning, develop preliminary form of product, preliminary field testing, main product revision, main field testing, operational product revision, operational field testing, final product revision, and dissemination and implementation.

Berdasarkan penjelasan di atas, maka rumusan masalah pada penelitian ini adalah bagaimana respon mahasiswa prodi Pendidikan Bahasa Arab terhadap buku ajar Morfologi Bahasa Arab Berbasis Analisis Konstrastif.

Subjek penelitian adalah 35 mahasiswa Prodi Pendidikan Bahasa Arab di Universitas KH. A. Wahab Hasbullah Jombang. Pendekatan yang dipilih adalah pendekatan kuantitatif. Pengumpulan data respon mahasiswa menggunakan instrumen angket. Mahasiswa dikondisikan dalam satu ruangan dan diberikan contoh buku ajar Morfologi Bahasa Arab

5 Abdul Mu'in, Analisis Kontrastif Bahasa Arab \& Bahasa Indonesia: Telaah terhadap Fonetik dan Morfologi (Jakarta: Pustaka Al Husna Baru, 2004), 5. 


\section{Siti Sulaikho', Lailatul Mathoriyah.}

Berbasis Analisis Konstrastif. Selanjutnya mereka memberikan penilaian terhadap buku ajar.

Data yang diperoleh berupa penilaian kuantitatif dan penilaian kualitatif yang berupa saran serta masukan. Data kuantitatif dianalisis menggunakan statistik deskriptif, sedangkan data kualitatif dinilai secara deskriptif.

\section{Kajian Pustaka}

Dalam artikelnya yang berjudul "Respon Mahasiswa IKIP Budi Utomo Terhadap Buku Ajar Matakuliah Biologi Sel Berbatuan Multimedia Interaktif”, Tri Asih Wahyu Hartati dan Dini Safitri menyebutkan tentang syarat khusus dalam menyusun buku ajar. Syarat tersebut antara lain: (1) memberikan orientasi terhadap teori, penalaran teori, dan cara-cara penerapan teori dalam praktik, (2) terdapat latihan terhadap pemakaian teori dan aplikasinya, (3) buku ajar memberikan umpan balik mengenai latihan tersebut, (4) menyesuaikan informasi dan tugas dengan tingkat perkembangan mahasiswa, (5) membangkitkan minat mahasiswa, (6) menjelaskan sasaran belajar kepada mahasiswa, (7) meningkatkan motivasi mahasiswa, serta (8) menunjukkan sumber informasi yang lain. ${ }^{6}$

Persamaan antara buku ajar yang disusun oleh Tri Asih Wahyu Hartati dan Dini Safitri dengan buku ajar yang disusun peneliti adalah mahasiswa sebagai sasaran dari pelaksanaan ujicoba ketika menyusun buku dan mahasiswa sebagai sasaran diterapkannya buku ajar.

Perbedaan dari keduanya adalah buku ajar yang disusun oleh Tri Asih Wahyu Hartati dan Dini Safitri berbasis multimedia interaktif, sedangkan buku ajar yang disusun peneliti adalah berbasis analisis kontrastif antara morfologi bahasa Arab dan morfologi bahasa

\footnotetext{
${ }^{6}$ Tri Asih Wahyu Hartati dan Dini Safitri, "Respon Mahasiswa IKIP Budi Utomo Terhadap Buku Ajar Matakuliah Biologi Sel Berbatuan Multimedia Interaktif”, Jurnal Pendidikan Biologi Indonesia, Volume 3 Nomor 2 (2017) : 166-167, diakses pada 4 Oktober 2019, http://ejournal.umm.ac.id/index.php/jpbi
} 


\section{Respon Mahasiswa Terhadap Buku Ajar Morfologi Bahasa Arab Berbasis Analisis}

Kontrastif

Indonesia.

Dalam artikelnya yang berjudul "Implikasi Analisis Kontrastif Kalimat Bahasa Arab dan Bahasa Indonesia dalam Meningkatkan Pemahaman Siswa”, Rosita Hasan menjelaskan tentang perbandingan antara kalimat dalam bahasa Arab dan kalimat dalam bahasa Indonesia. ${ }^{7}$

Persamaan antara penelitian yang dilakukan oleh Rosita Hasan dan peneliti adalah penggunaan analisis kontrastif sebagai alat untuk memperbandingkan kedua bahasa. Selain itu, bahasa yang digunakan antara Rosita Hasan dan peneliti adalah bahasa Arab dan Bahasa Indonesia.

Perbedaan yang dapat ditemukan antara kedua penelitian ini adalah Rosita Hasan mengambil bidang sintaksis dari unsur bahasa, sedangkan peneliti mengambil aspek morfologi. Perbedaan lainnya adalah Rosita Hasan hanya mengambil satu aspek dari bidang sintaksis, sedangkan peneliti mengambil keseluruhan aspek morfologi yang kemudian disusun menjadi buku ajar. Selain itu, sasaran dari penelitian yang dilakukan oleh Rosita Hasan adalah siswa, sedangkan sasaran penelitian dari peneliti adalah mahasiswa.

7 Rosita Hasan, "Implikasi Analisis Kontrastif Kalimat Bahasa Arab Dan Bahasa Indonesia Dalam Meningkatkan Pemahaman Siswa", Jurnal Shaut Al-Arabiyyah, Volume 6 Nomor 1 (2018), diakses pada 4 Oktober 2019, http://journal.uin-alauddin.ac.id/index.php/Shautul-Arabiyah/article/view/4801 


\section{Analisis Kebutuhan Mahasiswa terhadap Buku Ajar}

Angket pertama yang disebarkan adalah tentang permasalahan mahasiswa dalam mempelajari morfologi bahasa Arab. Angket ini disebarkan kepada 35 mahasiswa. Masingmasing mahasiswa memilih satu poin yang paling sesuai dengan pengalaman belajar mereka.

Tabel 1 : Distribusi Frekuesi Respon Mahasiswa

Terhadap Permasalahan Mempelajari Morfologi Bahasa Arab

\begin{tabular}{|l|c|c|}
\hline \multicolumn{1}{|c|}{ Pernyataan } & Frekuensi & $\%$ \\
\hline $\begin{array}{l}\text { Sulit membedakan istilah-istilah yang } \\
\text { terdapat dalam morfologi bahasa Arab }\end{array}$ & 8 & $22,9 \%$ \\
\hline $\begin{array}{l}\text { Contoh yang digunakan selalu sama pada } \\
\text { setiap pembahasan sehingga } \\
\text { membingungkan }\end{array}$ & 5 & $14,3 \%$ \\
\hline $\begin{array}{l}\text { Sulit mencari contoh selain yang sudah } \\
\text { dijelaskan }\end{array}$ & 6 & $17,1 \%$ \\
\hline $\begin{array}{l}\text { Satu kata dapat berubah menjadi banyak } \\
\text { bentuk lainnya }\end{array}$ & 3 & $8,6 \%$ \\
\hline $\begin{array}{l}\text { Tidak mengetahui maksud dari setiap } \\
\text { perubahan kata }\end{array}$ & 5 & $14,3 \%$ \\
\hline $\begin{array}{l}\text { Sulit menterjemahkan ke dalam bahasa } \\
\text { Indonesia sehingga tidak mudah dipahami }\end{array}$ & $\mathbf{3 5}$ & $\mathbf{1 0 0 \%}$ \\
\hline $\begin{array}{l}\text { Sulit mendapatkan sumber belajar yang } \\
\text { mudah dipahami }\end{array}$ & 4 & $11,4 \%$ \\
\hline
\end{tabular}

Angket selanjutnya yang diberikan adalah mengenai kebutuhan mahasiswa terhadap kebutuhan sumber belajar morfologi bahasa Arab.

\section{Tabel 2 : Distribusi Frekuesi Respon Mahasiswa}


Respon Mahasiswa Terhadap Buku Ajar Morfologi Bahasa Arab Berbasis Analisis

Kontrastif

\section{Terhadap Kebutuhan Sumber Belajar Morfologi Bahasa Arab}

\begin{tabular}{|l|c|c|}
\hline \multicolumn{1}{|c|}{ Pernyataan } & Frekuensi & $\%$ \\
\hline 1 - Sangat Tidak Setuju & 0 & 0 \\
\hline 2 - Tidak Setuju & 0 & 0 \\
\hline 3 - Setuju & 12 & 34,3 \\
\hline 4 - Sangat Setuju & 23 & 65,7 \\
\hline \multicolumn{1}{|c|}{ Total } & $\mathbf{3 5}$ & $\mathbf{1 0 0 \%}$ \\
\hline
\end{tabular}

\section{Analisis Hasil Validasi Ahli Materi dan Ahli Bahasa}

Sebelum diujikan terhadap mahasiswa, buku ajar Morfologi Bahasa Arab Berbasis Analisis Konstrastif telah melalui validasi ahli materi dan ahli bahasa. Adapun hasil validasi dari kedua ahli adalah sebagai berikut:

Tabel 3 : Validasi Ahli Materi

\begin{tabular}{|l|l|l|l|l|c|}
\hline \multirow{2}{*}{ No. } & \multicolumn{2}{|c|}{ Kriteria } & \multicolumn{3}{c|}{ Penilaian } \\
\cline { 4 - 6 } & \multicolumn{2}{|c|}{ Aspek Pembelajaran } & 1 & 3 & 4 \\
\hline 1. & Kejelasan tujuan pembelajaran & & & $\sqrt{ }$ \\
\hline 2. & Relevansi tujuan pembelajaran dengan kurikulum & & & & $\sqrt{ }$ \\
\hline 3. & Cakupan dan kedalaman tujuan pembelajaran & & & $\sqrt{ }$ & \\
\hline 4. & Kesesuaian materi dengan tujuan pembelajaran & & & & $\sqrt{ }$ \\
\hline 5. & Kesesuaian media dengan tujuan pembelajaran & & & & $\sqrt{ }$ \\
\hline 6. & Kesesuaian evaluasi dengan tujuan pembelajaran & & & & $\sqrt{ }$ \\
\hline 7. & Ketepatan penggunaan strategi pembelajaran & & & $\sqrt{ }$ & \\
\hline 8. & Sistematika yang runtut, logis dan jelas & & & & $\sqrt{ }$ \\
\hline 9. & Interaktif & & & $\sqrt{ }$ & \\
\hline 10. & Kontekstual & & & $\sqrt{ }$ & \\
\hline 11. & Kejelasan uraian, bahasan, contoh, dan latihan & & & & $\sqrt{ }$ \\
\hline 12. & Kemudahan untuk dipahami & & & & $\sqrt{ }$ \\
\hline
\end{tabular}




\begin{tabular}{|l|l|l|l|l|l|}
\hline \multicolumn{2}{|c|}{ Substansi Materi } & & & & $\sqrt{ }$ \\
\hline 13. & Kelengkapan materi & & & & $\sqrt{ }$ \\
\hline 14. & Keluasan materi & & & & $\sqrt{ }$ \\
\hline 15. & Keakuratan konsep dan definisi & & & & $\sqrt{ }$ \\
\hline 16. & Keakuratan contoh & & & & $\sqrt{ }$ \\
\hline 17. & Keakuratan soal & & & & $\sqrt{ }$ \\
\hline 18. & Keakuratan gambar, diagram dan ilustrasi & & & $\sqrt{ }$ & \\
\hline 19. & Keakuratan notasi, simbol dan icon & & & & \\
\hline
\end{tabular}

Tabel 4 : Validasi Ahli Bahasa

\begin{tabular}{|c|c|c|c|c|c|}
\hline \multirow{2}{*}{ No. } & \multirow{2}{*}{ Kriteria } & \multicolumn{4}{|c|}{ Penilaian } \\
\hline & & 1 & 2 & 3 & 4 \\
\hline 1. & Ketepatan pengunaan kaidah bahasa Arab & & & & $\sqrt{ }$ \\
\hline 2. & Ketepatan penggunaan kaidah bahasa Indonesia & & & & $\sqrt{ }$ \\
\hline 3. & $\begin{array}{l}\text { Ketepatan penggunaan istilah yang sesuai dengan } \\
\text { pokok bahasan }\end{array}$ & & & & $\sqrt{ }$ \\
\hline 4. & Ketepatan pemilihan kosa kata, kalimat dan ejaan & & & & $\sqrt{ }$ \\
\hline 5. & Menggunakan bahasa komunikatif & & & $\sqrt{ }$ & \\
\hline 6. & Konsistensi penggunaan tanda baca dan simbol & & & & $\sqrt{ }$ \\
\hline 7. & Konsistensi penggunaan istilah & & & & $\sqrt{ }$ \\
\hline 8. & $\begin{array}{l}\text { Pemilihan kata dan kalimat yang sederhana, jelas, } \\
\text { umum dan tidak berbelit-belit }\end{array}$ & & & & $\sqrt{ }$ \\
\hline 9. & $\begin{array}{l}\text { Kalimat yang digunakan mewakili isi pesan atau } \\
\text { informasi yang ingin disampaikan }\end{array}$ & & & & $\sqrt{ }$ \\
\hline
\end{tabular}

\section{Analisis Penilaian Mahasiswa Terhadap Buku Ajar}

Data yang diperoleh dari uji keterbacaan adalah data penilaian buku ajar Morfologi Bahasa Arab Berbasis Analisis Konstrastif yang berupa angka, serta data saran atau masukan 
secara deskriptif.

Terdapat 15 butir yang dinilai secara kuantitatif oleh mahasiswa.

Tabel 5 : Butir Penilaian Buku Ajar

\section{Morfologi Bahasa Arab Berbasis Analisis Konstrastif}

\begin{tabular}{|c|c|}
\hline Butir & Aspek Penilaian \\
\hline 1. & Tampilan sampul membuat tertarik untuk menggunakan buku ajar \\
\hline 2. & Topik/judul bab membuat tertarik untuk mempelajari buku ajar \\
\hline 3. & $\begin{array}{l}\text { Sistematika penyajian materi memudahkan untuk memahami materi buku } \\
\text { ajar }\end{array}$ \\
\hline 4. & Materi sesuai dengan tujuan pembelajaran \\
\hline 5. & $\begin{array}{l}\text { Tujuan pembelajaran mempermudah untuk mengetahui kemampuan apa } \\
\text { yang harus dikuasai setelah mempelajari tiap-tiap bab }\end{array}$ \\
\hline 6. & $\begin{array}{l}\text { Latihan/evaluasi membantu mengukur pemahaman materi yang telah } \\
\text { dipelajari }\end{array}$ \\
\hline 7. & Tabel dan diagram mempermudah memahami isi buku ajar \\
\hline 8. & $\begin{array}{l}\text { Bahasa yang digunakan memudahkan untuk memahami materi dalam buku } \\
\text { ajar }\end{array}$ \\
\hline 9. & $\begin{array}{l}\text { Bahasa dalam buku ajar komunikatif, sehingga menyenangkan selama } \\
\text { mempelajari buku ajar }\end{array}$ \\
\hline 10. & Bahasa sesuai dengan struktur tata bahasa Arab \\
\hline 11. & Bahasa sesuai dengan PUEBI (Pedoman Umum Ejaan Bahasa Indonesia) \\
\hline 12. & Istilah dalam buku ajar mudah dipahami dan konsisten \\
\hline 13. & $\begin{array}{l}\text { Hasil analisis kontrastif pada setiap bab membantu untuk mempercepat } \\
\text { pemahaman }\end{array}$ \\
\hline 14. & $\begin{array}{l}\text { Contoh yang dicantumkan dalam buku ajar sesuai dengan kehidupan sehari- } \\
\text { hari sehingga mudah diingat }\end{array}$ \\
\hline 15. & $\begin{array}{l}\text { Buku ajar membantu proses belajar, baik secara mandiri atau dalam } \\
\text { perkuliahan }\end{array}$ \\
\hline
\end{tabular}


Siti Sulaikho', Lailatul Mathoriyah.

Mahasiswa secara bebas memberikan penilaian secara kuantitatif terhadap setiap butir.

Data kuantitatif ini kemudian diambil nilai rata-rata pada setiap butirnya.

Tabel 6 : Penilaian Mahasiswa Terhadap Butir

Buku Ajar Morfologi Bahasa Arab Berbasis Analisis Konstrastif

\begin{tabular}{|c|c|c|c|c|c|c|c|c|c|c|c|c|c|c|c|}
\hline \multirow{2}{*}{$\begin{array}{l}\text { Maha } \\
\text { siswa }\end{array}$} & \multicolumn{15}{|c|}{ Butir Penilaian } \\
\hline & 1 & 2 & 3 & 4 & 5 & 6 & 7 & 8 & 9 & 10 & 11 & 12 & 13 & 14 & 15 \\
\hline 1. & 93 & 88 & 89 & 75 & 93 & 86 & 93 & 89 & 92 & 87 & 94 & 91 & 88 & 83 & 86 \\
\hline 2. & 98 & 89 & 97 & 80 & 87 & 92 & 89 & 93 & 88 & 96 & 93 & 86 & 91 & 90 & 96 \\
\hline 3. & 80 & 83 & 87 & 85 & 92 & 84 & 94 & 84 & 92 & 82 & 78 & 87 & 89 & 94 & 92 \\
\hline 4. & 98 & 89 & 96 & 75 & 88 & 93 & 92 & 78 & 88 & 97 & 96 & 87 & 80 & 87 & 90 \\
\hline 5. & 95 & 93 & 97 & 98 & 94 & 92 & 90 & 91 & 93 & 89 & 88 & 93 & 92 & 89 & 90 \\
\hline 6. & 87 & 80 & 83 & 85 & 87 & 80 & 93 & 89 & 92 & 90 & 91 & 88 & 84 & 87 & 91 \\
\hline 7. & 98 & 96 & 98 & 79 & 77 & 89 & 91 & 87 & 93 & 85 & 95 & 83 & 97 & 89 & 96 \\
\hline 8. & 96 & 92 & 89 & 90 & 96 & 94 & 89 & 84 & 91 & 95 & 92 & 87 & 86 & 85 & 90 \\
\hline 9. & 86 & 87 & 91 & 90 & 89 & 96 & 94 & 78 & 94 & 82 & 91 & 90 & 89 & 76 & 83 \\
\hline 10. & 94 & 84 & 89 & 95 & 94 & 87 & 88 & 98 & 94 & 86 & 87 & 89 & 90 & 94 & 95 \\
\hline 11. & 92 & 90 & 94 & 80 & 88 & 92 & 86 & 90 & 84 & 92 & 88 & 92 & 90 & 92 & 96 \\
\hline 12. & 88 & 86 & 90 & 88 & 92 & 86 & 94 & 90 & 84 & 92 & 86 & 90 & 98 & 94 & 98 \\
\hline 13. & 83 & 87 & 85 & 75 & 83 & 87 & 91 & 93 & 97 & 89 & 91 & 89 & 93 & 95 & 97 \\
\hline 14. & 90 & 88 & 91 & 89 & 92 & 87 & 85 & 92 & 89 & 90 & 94 & 97 & 89 & 94 & 95 \\
\hline 15. & 94 & 88 & 92 & 88 & 92 & 94 & 90 & 86 & 84 & 92 & 94 & 88 & 90 & 92 & 98 \\
\hline 16. & 87 & 89 & 91 & 85 & 87 & 91 & 93 & 97 & 95 & 87 & 89 & 93 & 95 & 89 & 93 \\
\hline 17. & 89 & 91 & 87 & 93 & 89 & 93 & 95 & 91 & 97 & 93 & 89 & 87 & 83 & 81 & 91 \\
\hline 18. & 90 & 92 & 90 & 96 & 92 & 88 & 94 & 96 & 98 & 92 & 90 & 88 & 92 & 94 & $\overline{96}$ \\
\hline 19. & 92 & 88 & 78 & 90 & 94 & 96 & 92 & 90 & 88 & 92 & 94 & 96 & 98 & 88 & 90 \\
\hline 20. & 86 & 88 & 90 & 86 & 92 & 96 & 98 & 96 & 92 & 82 & 88 & 88 & 92 & 96 & 98 \\
\hline 21. & 89 & 91 & 87 & 93 & 89 & 91 & 87 & 93 & 95 & 97 & 89 & 91 & 95 & 93 & 95 \\
\hline 22. & 94 & 92 & 90 & 88 & 94 & 92 & 88 & 90 & 84 & 92 & 90 & 92 & 94 & 88 & 94 \\
\hline 23. & 96 & 96 & 94 & 92 & 88 & 90 & 88 & 90 & 92 & 94 & 96 & 88 & 92 & 94 & $\overline{96}$ \\
\hline 24. & 98 & 90 & 88 & 90 & 92 & 94 & 96 & 98 & 92 & 94 & 96 & 88 & 90 & 92 & 94 \\
\hline 25. & 88 & 90 & 92 & 94 & 90 & 88 & 94 & 92 & 88 & 92 & 90 & 92 & 94 & 88 & 92 \\
\hline 26. & 87 & 89 & 91 & 93 & 87 & 89 & 93 & 97 & 91 & 89 & 97 & 95 & 93 & 91 & 93 \\
\hline 27. & 89 & 87 & 93 & 95 & 89 & 93 & 95 & 97 & 93 & 91 & 89 & 93 & 91 & 95 & 97 \\
\hline 28. & 92 & 90 & 94 & 86 & 92 & 90 & 92 & 94 & 96 & 92 & 88 & 94 & 92 & 98 & 98 \\
\hline 29. & 94 & 90 & 92 & 96 & 92 & 94 & 88 & 92 & 94 & 96 & 94 & 98 & 92 & 90 & 96 \\
\hline 30. & 88 & 90 & 92 & 94 & 92 & 88 & 92 & 96 & 94 & 92 & 96 & 94 & 92 & 90 & 98 \\
\hline 31. & 98 & 88 & 92 & 94 & 88 & 92 & 94 & 90 & 92 & 94 & 88 & 90 & 88 & 94 & 92 \\
\hline 32. & 89 & 91 & 89 & 93 & 95 & 97 & 93 & 91 & 97 & 95 & 89 & 87 & 89 & 91 & 93 \\
\hline 33. & 95 & 83 & 85 & 91 & 93 & 89 & 93 & 95 & 89 & 87 & 83 & 91 & 93 & 91 & 95 \\
\hline 34. & 98 & 92 & 94 & 92 & 90 & 92 & 94 & 98 & 94 & 92 & 96 & 94 & 92 & 96 & 98 \\
\hline 35. & 92 & 94 & 92 & 80 & 86 & 88 & 94 & 88 & 90 & 92 & 94 & 92 & 96 & 94 & 96 \\
\hline
\end{tabular}


Respon Mahasiswa Terhadap Buku Ajar Morfologi Bahasa Arab Berbasis Analisis

Kontrastif

\begin{tabular}{|c|c|c|c|c|c|c|c|c|c|c|c|c|c|c|c|}
\hline $\begin{array}{c}\text { Rata- } \\
\text { rata }\end{array}$ & 91.5 & 89.2 & 90.5 & 88.4 & 90.1 & 90.6 & 91.8 & 91.2 & 91.6 & 90.8 & 90.9 & 90.5 & 91.1 & 90.7 & 93.9 \\
\hline
\end{tabular}

Nilai rata-rata tiap butir ini kemudian dijumlahkan kembali dan diambil nilai rata-rata selanjutnya. Adapun layak atau tidaknya hasil dari penilaian akhir, dikategorikan berdasarkan acuan penilaian berikut :

Tabel 7 : Acuan Nilai Kelayakan Buku Ajar

\begin{tabular}{|c|c|}
\hline Keterangan & Nilai \\
\hline Sangat Bagus & $90-100$ \\
\hline Bagus & $80-89,9$ \\
\hline Cukup & $70-79,9$ \\
\hline Kurang & $60-54,9$ \\
\hline
\end{tabular}

Tabel 8 : Penilaian Mahasiswa Terhadap Buku Ajar Morfologi Bahasa Arab Berbasis Analisis Konstrastif

\begin{tabular}{|l|l|c|l|}
\hline No. & \multicolumn{1}{|c|}{ Aspek } & Penilaian & \multicolumn{1}{c|}{ Kelayakan } \\
\hline 1. & $\begin{array}{l}\text { Tampilan sampul membuat tertarik untuk } \\
\text { menggunakan buku ajar }\end{array}$ & 91,5 & $\begin{array}{l}\text { Layak dengan predikat } \\
\text { sangat bagus }\end{array}$ \\
\hline 2. & $\begin{array}{l}\text { Topik/judul bab membuat tertarik untuk } \\
\text { mempelajari buku ajar }\end{array}$ & 89,2 & $\begin{array}{l}\text { Layak dengan predikat } \\
\text { bagus }\end{array}$ \\
\hline 3. & $\begin{array}{l}\text { Sistematika penyajian materi memudahkan } \\
\text { untuk memahami materi buku ajar }\end{array}$ & 90,5 & $\begin{array}{l}\text { Layak dengan predikat } \\
\text { sangat bagus }\end{array}$ \\
\hline 4. & $\begin{array}{l}\text { Materi sesuai dengan tujuan pembelajaran } \\
\text { mengetahui kemampuan apa yang harus } \\
\text { dikuasai setelah mempelajari tiap-tiap bab }\end{array}$ & 90,1 & $\begin{array}{l}\text { Layak dengan predikat } \\
\text { bagus }\end{array}$ \\
\hline 5. & $\begin{array}{l}\text { Tujuan pembelajaran mempermudah untuk } \\
\text { sangagus }\end{array}$ \\
\hline 6. & \begin{tabular}{l} 
Latihan/evaluasi membantu mengukur \\
\hline
\end{tabular} & 90,6 & Layak dengan predikat \\
\hline
\end{tabular}




\begin{tabular}{|c|c|c|c|}
\hline & pemahaman materi yang telah dipelajari & & sangat bagus \\
\hline 7. & $\begin{array}{l}\text { Tabel dan diagram mempermudah } \\
\text { memahami isi buku ajar }\end{array}$ & 91,8 & $\begin{array}{l}\text { Layak dengan predikat } \\
\text { sangat bagus }\end{array}$ \\
\hline 8. & $\begin{array}{l}\text { Bahasa yang digunakan memudahkan untuk } \\
\text { memahami materi dalam buku ajar }\end{array}$ & 91,2 & $\begin{array}{l}\text { Layak dengan predikat } \\
\text { sangat bagus }\end{array}$ \\
\hline 9. & $\begin{array}{l}\text { Bahasa dalam buku ajar komunikatif, } \\
\text { sehingga menyenangkan selama } \\
\text { mempelajari buku ajar }\end{array}$ & 91,6 & $\begin{array}{l}\text { Layak dengan predikat } \\
\text { sangat bagus }\end{array}$ \\
\hline 10. & $\begin{array}{l}\text { Bahasa sesuai dengan struktur tata bahasa } \\
\text { Arab }\end{array}$ & 90,8 & $\begin{array}{l}\text { Layak dengan predikat } \\
\text { sangat bagus }\end{array}$ \\
\hline 11. & $\begin{array}{l}\text { Bahasa sesuai dengan PUEBI (Pedoman } \\
\text { Umum Ejaan Bahasa Indonesia) }\end{array}$ & 90,9 & $\begin{array}{l}\text { Layak dengan predikat } \\
\text { sangat bagus }\end{array}$ \\
\hline 12. & $\begin{array}{l}\text { Istilah dalam buku ajar mudah dipahami dan } \\
\text { konsisten }\end{array}$ & 90,5 & $\begin{array}{l}\text { Layak dengan predikat } \\
\text { sangat bagus }\end{array}$ \\
\hline 13. & $\begin{array}{l}\text { Hasil analisis kontrastif pada setiap bab } \\
\text { membantu untuk mempercepat pemahaman }\end{array}$ & 91,1 & $\begin{array}{l}\text { Layak dengan predikat } \\
\text { sangat bagus }\end{array}$ \\
\hline 14. & $\begin{array}{l}\text { Contoh yang dicantumkan dalam buku ajar } \\
\text { sesuai dengan kehidupan sehari-hari } \\
\text { sehingga mudah diingat }\end{array}$ & 90,7 & $\begin{array}{l}\text { Layak dengan predikat } \\
\text { sangat bagus }\end{array}$ \\
\hline 15. & $\begin{array}{l}\text { Buku ajar membantu proses belajar, baik } \\
\text { secara mandiri atau dalam perkuliahan }\end{array}$ & 93,9 & $\begin{array}{l}\text { Layak dengan predikat } \\
\text { sangat bagus }\end{array}$ \\
\hline & Rata-rata & 90,8 & $\begin{array}{l}\text { Layak dengan predikat } \\
\text { sangat bagus }\end{array}$ \\
\hline
\end{tabular}

\section{Penutup}

Kebutuhan akan buku ajar morfologi bahasa Arab terbilang sangat mendesak. Hal ini dibuktikan dengan prosentasi 65,7\% mahasiswa yang menyatakan sangat setuju dengan disusunnya buku ajar morfologi, sedangkan 34,3\% lainnya menyatakan setuju. 


\section{Respon Mahasiswa Terhadap Buku Ajar Morfologi Bahasa Arab Berbasis Analisis Kontrastif}

Buku ajar Morfologi Bahasa Arab Berbasis Analisis Kontrastif bertujuan untuk mempermudah mahasiswa dalam mempelajari morfologi bahasa Arab, baik secara mandiri atau di dalam kelas.

Buku ajar Morfologi Bahasa Arab Berbasis Analisis Kontrastif telah melalui uji validasi dari ahli materi dan ahli bahasa. Setelah melakukan perbaikan dn mendapatkan penilaian yang baik, selanjutnya buku ajar ditunjukkan kepada 35 mahasiswa prodi Pendidikan Bahasa Arab di Universitas KH. A. Wahab Hasbullah Jombang untuk mendapatan penilaian. Penilaian yang dilakukan oleh mahasiswa bertujuan untuk mengetahui respon mereka terhadap buku ajar.

Berdasarkan penilaian menyeluruh terhadap 15 butir penilaian, hasil akhir menunjukkan bahwa buku ajar Morfologi Bahasa Arab Berbasis Analisis Kontrastif mendapatkan nilai 90,8 dengan kategori layak dan predikat sangat bagus.

\section{Daftar Pustaka}

Hartati, Tri Asih Wahyu dan Dini Safitri, "Respon Mahasiswa IKIP Budi Utomo Terhadap Buku Ajar Matakuliah Biologi Sel Berbatuan Multimedia Interaktif', Jurnal Pendidikan Biologi Indonesia, Volume 3 Nomor 2 Tahun 2017, diakses pada 4 Oktober 2019, http://ejournal.umm.ac.id/index.php/jpbi

Hasan, Rosita "Implikasi Analisis Kontrastif Kalimat Bahasa Arab Dan Bahasa Indonesia Dalam Meningkatkan Pemahaman Siswa", Jurnal Shaut Al-Arabiyyah, Volume 6 Nomor 1 Tahun 2018, diakses pada 4 Oktober 2019, http://journal.uinalauddin.ac.id/index.php/Shautul-Arabiyah/article/view/4801

Lyons, John. Pengantar Teori Linguistik. Jakarta: Gramedia Pustaka Utama. 1995. 
Siti Sulaikho', Lailatul Mathoriyah.

Maulana, Muhamad Ichsan. Belajar Shorof Tanpa Guru. Kediri: Lirboyo Press. 2015.

Mu'in, Abdul. Analisis Kontrastif Bahasa Arab \& Bahasa Indonesia: Telaah terhadap Fonetik dan Morfologi. Jakarta: Pustaka Al Husna Baru. 2004.

Nurbayan, Yayan. "Pengembangan Materi Ajar Balaghah Berbasis Pendekatan Kontrastif". Jurnal Bahasa dan Seni, Volume 38 No. 1, Februari 2010.

Pringgawidagda, Suwarna. Strategi Penguasaan Berbahasa. Yogyakarta: Adicita Karya Nusa. 2002. 